\title{
UNPRECEDENTED RECORD OF UNIQUE BRYDE'S WHALE (BALAENOPTERA EDENI) OFF THE SOUTHERN COAST OF THE MARINE ENVIRONMENTAL PROTECTION AREA, SÃO PAULO STATE, BRAZIL
}

\author{
BARBIERI, E. ${ }^{1}$; ROSELLI, L. Y.. ${ }^{2 *}$ QUITO, L. ${ }^{3}$ \\ *Corresponding author: larissa.yoshida.roselli@hotmail.com \\ 1. Instituto de Pesca - APTA - Secretaria de Agricultura e Abastecimento - Governo SP \\ 2. Programa de pós-graduação em Biodiversidade de Ambientes Costeiros - UNESP \\ 3. Fundação Florestal - Secretaria de Infraestrutura e Meio Ambiente - Governo SP
}

\begin{abstract}
Barbieri, E. ${ }^{1}$, Roselli, L. Y.' ${ }^{2}$, Quito, L. ${ }^{3}$ A Unprecedented record of Bryde's whale in South Coast MPA, SP, Brazil. Braz. J. Aquat. Sci. Technol. 23(1). eISSN 1983-9057. DOI: 14117/bjast.v23n1. This note documents the first record of a Bryde's whale (Balaenoptera edeni) in the South Coast Marine Environmental Protected Area (SCMEPA) São Paulo State, Brazil. This observation was made during the monitoring activity of the protected area, on December 7, 2016, when two specimens were sighted near the Cardoso Island, south coast of the São Paulo State. Bryde's whale observations are still very limited on the Brazilian coast, so this record represents important source for subsidizing policies of environmental planning for the SCMEPA.
\end{abstract}

Key Words: Bryde's whale, Record, São Paulo coast, Cardoso Island.

\section{INTRODUCTION}

The Bryde's whale (Balaenoptera edeni Anderson son, 1879) belongs to Balaenopteridae family and is distributed worldwide in tropical and subtropical waters between $40^{\circ} \mathrm{N}$ and $40^{\circ} \mathrm{S}$ parallels, living in warm ocean waters, with temperatures ranging from 15 to $20^{\circ} \mathrm{C}$ (Gonçalves \& Andriolo, 2006).

The Bryde's whale has a slender and hydrodynamic body, with a broad head showing three parallel ridges running from the blow-holes to the v-shaped snout, a diagnostic feature for the species (Monteiro-Filho et al., 2013). Sexual dimorphism is not evident, with males ranging from 12 to 13 meters while females are slightly larger, varying from 13 to 15.5 meters. Both sexes weigh from 13,600 to 15,000 $\mathrm{kg}$ (Wiseman et al., 2011). The body's color is predominantly dark gray or black on the back, becoming light gray or white on the abdomen. Circular scars of lampreys and sharks may be visible in more migratory individuals (Allen et al., 2011). On the throat, 54 to 56 grooves occur between each fin and extend beyond their navel. Their dorsal fins are high, curved, with a sharp tip, while the pectoral fins are short, narrow and pointed (Shirihai, 2006; Jefferson et al., 2008; Allen et al., 2011).

The little information concerning the species indicate that they feed primarily on small fish such as sardines (Sardinella spp.) and anchovies (Anchoviella spp.) (Siciliano et al., 2004; Lodi et al., 2015) and they consume about $4 \%$ of their body mass per day, which corresponds to about $600-660 \mathrm{~kg}$ of food (Allen et al., 2011). They can dive up to 300 meters depth (Shirihai, 2006; Jefferson et al., 2008; Allen et al., 2011) by pursuing prey.

The species is distributed along the Brazilian coast, from Maranhão to Rio Grande do Sul, but mainly in the southeastern and southern regions during the summer and the austral autumn (Zerbini et al., 1997; Siciliano et al., 2004; Gonçalves et al., 2015; Lodi et al., 2015). Although there are sporadic records on the coast of São Paulo State, most of them correspond to beach-bound events (Santos et al., 2010; PETROBRAS, 2016; PETROBRAS, 2018) and little is known about the populations of this species on the coast of the State.

Information on ecology, behavior, genetics and life history are poorly understood, which is why the species is considered internationally (IUCN, 2018) and nationally (BRASIL, 2014) as Data Deficient (DD). Therefore, aspects such as population size, home ranges displacement patterns and longevity, are unknown. Thus, this occurrence note becomes an important record of the species for the São Paulo State, specifically for the South Coast Marine Environmental Protected Area (SCMEPA). 


\section{MATERIAL AND METHODS}

The SCMEPA was created in 2008 (State Decree 53.527/2008) with the objective of protecting, ordering, guaranteeing and disciplining the rational use of environmental resources, including its waters, as well as recreational tourism, research and fishing activities, aiming to promote the sustainable development of the region. It has 368742.53 ha of area covering the coastal region of the municipalities of Cananeia, Ilha Comprida and Iguape (Reigala et al., 2014; Collaço et al., 2015). Its limits off the coast ranges from the maximum high tide up to the 25-meter isobaths (Figure 1).

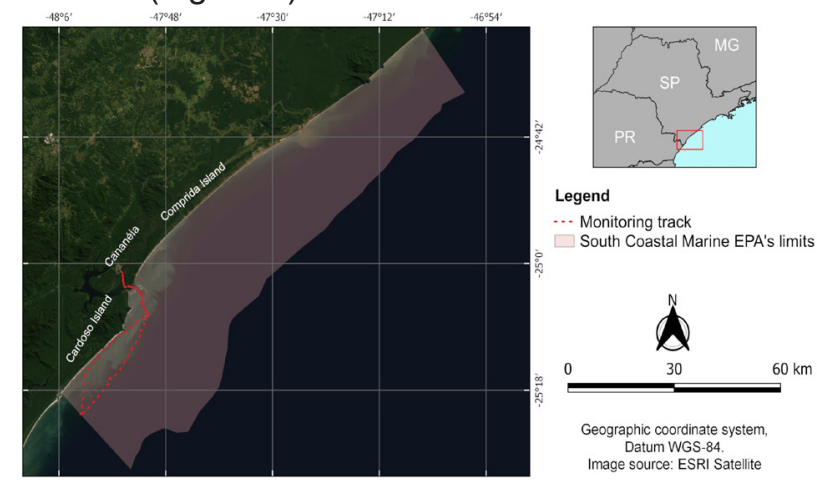

Figure 1 - Map illustrating the location of the Marine EPA of the São Paulo State, and monitoring track (in red) conducted during the expedition carried out on December 7, 2016.

Amongst the activities developed to achieve the SCMEPA's objectives, monthly expeditions are carried out for environmental monitoring in which the main activities and verified uses of the territory, possible environmental impacts, and biota species sighted in the expedition are registered (Reigala et al., 2014). The survey was performed on December 7, 2016, from 8:30 a.m. to 12:30 p.m., using a 25 -ft boat with two outboard motors, along the length of the SCMEPA (Figure 1). At the moment of the whale's sighting, the boat slowed speed to avoid disturbing their natural behavior and photographs and GPS coordinates were taken to register the presence of animals

\section{RESULTS AND DISCUSSION}

During the expedition, two specimens of Bryde's whales were observed and photographed on the SCMPA between 9:11 and 9:23 a.m. in the immediate vicinity of Cardoso Island, between Bom Abrigo Island and Cambriú Island (Figure 2).

The whales swam very close to each other, moving slowly to the northeast, when it was possible to notice a high spray of more than one meter in height, characteristic of the species (Figure 3), followed by the exposure of the dorsal fin with little exposure of the body at the surface of the water during swimming (Figure 4), and failing to expose the caudal fin when diving. In addition, the pattern of dark-gray coloration was verified on the dorsum becoming latero-ventrally clearer, the robust $\mathrm{V}$-shaped snout and the high, falcate and sharply tipped dorsal fin (Perrin et al., 2009).

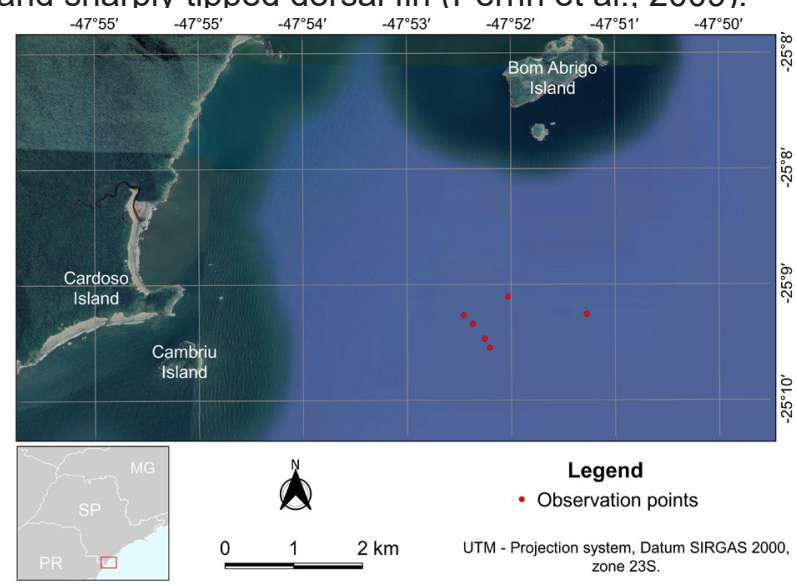

Figure 2 - Map illustrating the location where the individuals of Balaenoptera edeni were observed at Southern Coast of the Marine EPA of the São Paulo State.

Bryde's whales are generally seen as solitary or in pairs and can be joined in groups of up to 20 individuals when in feeding grounds, while those groups living farther off the coast can hold up to 30 individuals (Wiseman et al., 2011). When traveling, 93\% of the Bryde's whales are solitary or in pairs (Jefferson et al., 2008). For this reason, we believe that the specimens sighted in the SCMEPA must be traveling, since in addition to the size of the group, they exhibited displacement behavior and were no longer seen along the returning path of the monitoring expedition.

Amongst the main potential threats recognized for this species in the SCMEPA are incidental catches in fishing artifacts, the reduction of food resources due to overfishing and noise pollution produced by vessels and sonars (BRASIL, 2011) which have been related to individual or collective stranding of other cetaceans (Reilly et al., 2008).

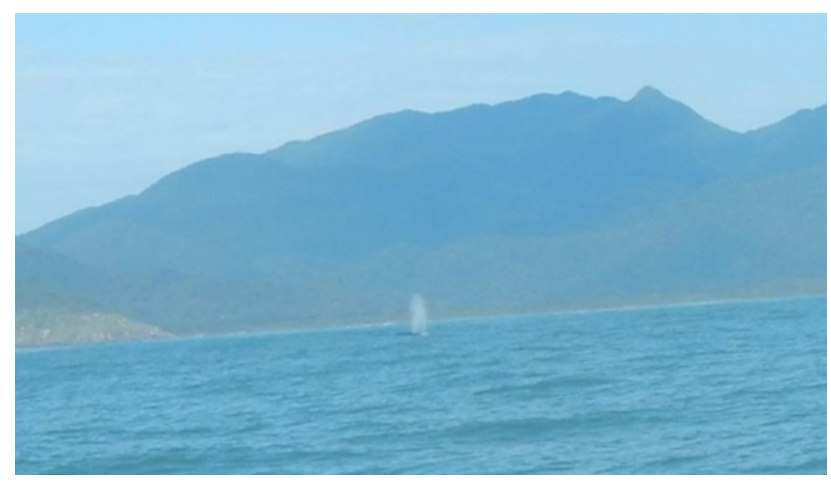

Figure 3 - Balaenoptera edeni, sighted in the South Coast Marine EPA, detected by spray. The Cardoso Island can be seen in the background. 
However, since the southern coast of the São Paulo State is still fairly well preserved with no larger-scale ports, industries or anthropic activities (Barbieri et al., 2010), the other threats associated with large cetaceans such as collisions with larger vessels, impact of sounds from seismic prospecting and oil and gas exploration, contamination by chemical pollutants, interaction with marine debris and disordered observation tourism (BRASIL, 2011) do not have a significant impact on the region.

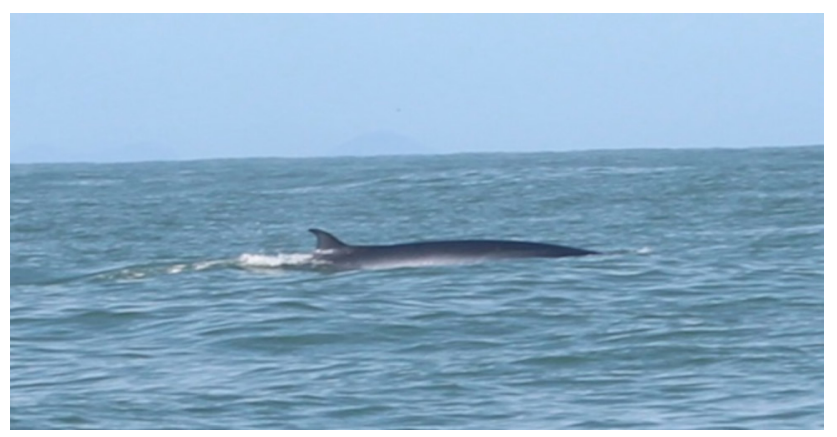

Figure 4 - Balaenoptera edeni moving on the surface of the water. Note the dark coloration on the back, turning gray on the side, as well as the low and falcated dorsal fin on the lower third of the body.

The SCMEPA is an integral part of the Mosaic of Conservation Units of LAGAMAR (BRASIL, 2006) and of the Mosaic of Islands and Protected Areas of the São Paulo Coast (SÃO PAULO, 2008). It is part of a continuum of marine and coastal ecosystems, including the Estuarine-Lagoon Complex of IguapeCananeia, considered one of the most productive and preserved ecosystems in the world, Natural Patrimony of Humanity (UNESCO, 2008) and RAMSAR Site (2017). Therefore, the occurrence of key species, top-of-the-food-chain and vulnerable species, such as the Bryde's whale, reinforces the importance of this ecosystem for marine biota and may be an indication that this area is an important habitat for species.

The marine fauna monitoring on board of small vessels is a tool of great importance for scientific research, mainly for creating opportunities to answer questions about fauna in distinct areas of the coast, such as seasonality, distribution, group size and determining areas of environmental sensitivity. Even though it is one brief recording, this occurrence is of great value, because it is an unpublished information for the region and it should be considered in decision-making and future regulation proposals by the SCMEPA.

It is therefore necessary to undertake efforts to continue and to systematize monitoring and research with Bryde's whales and other cetaceans in the region, so that is possible to more accurately assess the use of the area as an important habitat for the Bryde's whale, the potential and effective impacts of human activities on the species, and to assist in the elaboration of the Management Plan and other public policies, in addition to, of course, increasing the knowledge concerning the species that use the SCMEPA.

\section{REFERENCES}

Allen, S.; Mortenson, J. \& Webb, S. 2011. Field guide to marine mammals of the Pacific Coast. California, US. University of California Press. 343p.

Andriolo, A.; Da Rocha, J. M.; Zerbini, A. N.; SimõesLopes, P. C.; Moreno, I. B., Lucena, A.; Danilewicz, D. \& Bassoi, M. 2010. Distribution and relative abundance of large whales in a former whaling ground off eastern South America. Zoologia. 27(5): 741-750.

Barbieri, E.; Gonçalves, C. A.\& Da Silveira, L.F. 2010. Ocorrência do Phalaropus tricolor (Vieillot, 1819) (Scolopacidae) no estuário da llha Comprida, São Paulo, Brasil. Pan. Am. JAS, 5(1):139-142.

Brasil. 2006. Portaria no 150, de 08 de maio de 2006. Diário Oficial da União, 93 (Seção 1): 73p.

Brasil. 2011. Plano de ação nacional para conservação dos mamíferos aquáticos: grandes cetáceos e pinípedes. Versão III. Rocha-Campos, C. C., Gusmão-Câmara, I. (orgs.). Brasília: Instituto Chico Mendes de Conservação da Biodiversidade. $156 \mathrm{p}$.

Brasil. 2014. Portaria $n^{\circ} 444$, de 17 de dezembro de 2014. Ministério do Meio Ambiente. Diário Oficial da União, 245 (Seção 1): 121-126.

Collaço, F. L.; Santor, S. M. \& Barbieri, E. 2015. Cultivo de Bijupirá (Rachycentron canadum) em Cananeia, SP, Brasil. Avaliação da viabilidade utilizando geoprocessamento. Revista da Gestão Costeira Integrada. 15(2): 277-289,

Gonçalves, L. R. \& Andriolo, A. 2006. Ocorrência, distribuição e comportamento de Baleias-de-bryde (Balaenoptera edeni Anderson, 1879) (Cetacea, Mysticeti) em áreas costais e oceânicas do sudeste do Brasil, Zoociências. 8(2): 213.

Gonçalves, L.R.; Augustowski, M. \& Andriolo, A. 2015. Occurrence, distribution and behaviour of Bryde's whales (Cetacea: Mysticeti) off south-east Brazil. J. Mar. Biol. Assoc. U. K., 96(4): 943-954.

Jefferson, T.; Webber, M. \& Pitman, R. 2008. Marine mammals of the Word: a comprehensive guide to their identification. London, England: Elsevier Publications. 324p.

Lima, A. F. B.; Gonsalvezm L. F. \& Queiroz, E. L. 2006. Registros históricos da Baleia-de-Brayde Balenoptera edeni Anderson, 1879 (Mysticeti, Balenopeteridae, no Rio Paraguaçu, Baía de Todos os Santos, Bahia, Brasil, Bioikos. 20(2): 75-79. 
Lodi, L.; Tardin, R. H.; Hetzel, B.; Maciel, I. S.; Figueiredo, L. D. \& Simão, S. M. 2015. Bryde's whale (Certatiodactyla: Balaenopteridae) occurrence and movements in coastal areas of southeastern Brazil, Zoologia. 32(1): 171-175.

Monteiro-Filho, E. L. A.; Oliveira, L. V.; Monteiro, K. D. K. A.; Filla, G. F.; Quito, L. \& Godoy, D. F. 2013. Guia llustrado de Mamíferos Marinhos do Brasil. Cananeia: Instituto de Pesquisas Cananeia. 108p.

Perrin, W. F.; Würsig, B. \& Thewissen, J. G. M. 2009. Encyclopedia of marine mammals. $2^{\circ}$ Edição. Academic Press, $1352 \mathrm{p}$.

PETROBRAS. 2016. Projeto de Monitoramento de Praias da Bacia de Santos - Fase 1: Relatório Técnico Anual (2015-2016) PMP-BS Fase 1 (Gerenciamento e Execução do Projeto de Monitoramento de Praias da Bacia de Santos Fase 1). Versão 00. (p. 136). Itajaí, SC: UNIVALI/ PETROBRAS.

PETROBRAS. 2018. Projeto de Monitoramento de Praias da Bacia de Santos - Fase 2: Relatório Técnico Anual (2016-2017) PMP-BS Fase 2 (Gerenciamento e Execução do Projeto de Monitoramento de Praias da Bacia de Santos Fase 2). Versão 00. (p. 360). Itajaí, SC: UNIVALI/ PETROBRAS.

RAMSAR. The Convention on Wetlands. Country Profiles. 2017. Accessed on 09 September 2019. At: https://rsis.ramsar.org/ ris/2310? language $=e n$.

Reigala, C.S.; Barbieri, E. \& Luchini, L. C. 2014. Presença de organoclorados em amostras de água e ostras Crassostrea sp. do município de Cananeia-SP. O Mundo da Saúde. 38(1): 66-74.

Reilly, S.; Bannister, P.; Best, M.; Brown, R.; Brownell, D.; Butterworth, P.; Claphan, J.; Cooker, G.; Donovan, J.; Urbán, J. \& Zerbini, A. 2008. Balaenoptera edeni. The IUCN Red List of Threatened Species 2008: e.T2476A9445502. http://dx.doi.org/10.2305/IUCN.UK.2008.RLTS. T2476A9445502.en. Accessed on 20 April 2018. At http://www.iucnredlist.otg/details/2476/0

Santos, M.C.D.O.; Siciliano, S.; Vicente, A.F.D.C.; Alvarenga, F.S.; Zampirolli, E.; Souza, S.P.D. \& Maranho, A. 2010. Cetacean records along São Paulo State coast, Southeastern Brazil. Brazil, J. Oceano. 58(2): 123- 42.

Shirihai, H. 2006. Whales, Dolphins, and other marine mammals of the world. Princeton, NJ: Princeton University Press. 143p.

Siciliano, S.; Oliveira-Santos, M. C.; Vicente, A. F.; Alvarenga, F. S.; Zampirolli, E.; Brito, J. L. \& Pizzorno, J. L. A. 2004. Strandings and feeding records of Bryde's whales (Balaenoptera edeni) in south-eastern Brazil, J. Mar. Biol. Assoc. U. K., 84(4): 857-859.

São Paulo. 2008. Decreto $n^{\circ} 53.528$, de 08 de outubro de 2008. Diário Oficial do Estado da São Paulo, 118 (191) (Seção I), 9p.

UNESCO. World Heritage Convention. 1999. Disponível em: http://whc.unesco.org/en/list/893/ multiple=1\&unique_number $=1045$. Acesso em: 09 set. 2019.

Wiseman, N.; Parsons, S.; Stockin, K. \& Baker, S. 2011. Seasonal occurence and distribution of Bryde's whales in the Hauraki Gulf, New Zealand. Mar. Mammal Sci., 27(4): 253-267.

Zerbini, A. N.; Secchi, E. R.; Siciliano, S. \& SimõesLopes, P. C. 1997. A review of the occurrence and distribution of whales of the genus Balaenoptera along the Brazilian coast. Report of the International Whaling Commission, 47: 407-417.
Submetido: Abril/19 Revisado: Agosto/19 Aceito: Outubro/19 Publicado: 17/04/20 